\title{
The Sexual Contract 30 Years on: A Conversation with Carole Pateman
}

\author{
Sharon Thompson ${ }^{1}$ (D) Lydia Hayes $^{1} \cdot$ Daniel Newman $^{1} \cdot$ Carole Pateman $^{2,3}$
}

Published online: 20 March 2018

(C) The Author(s) 2018

\begin{abstract}
This reflection is based on a conversation with Professor Carole Pateman on 4th December 2017 as we prepared for a conference at Cardiff University to celebrate the thirtieth anniversary of her seminal work, The Sexual Contract (1988). As socio-legal scholars, The Sexual Contract has been formative in, and transformative of, our understandings of law and gender. We explore Professor Pateman's academic journey and consider how she came to write a ground-breaking book that has made major impacts on socio-legal and feminist legal studies. The paper is structured around the main themes arising in conversation with Pateman, with each section centred on her own account taken from our conversation in late 2017.
\end{abstract}

Keywords Feminism $\cdot$ Biography $\cdot$ Patriarchies $\cdot$ Sexual contract $\cdot$ Social contract $\cdot$ Settler contract

\section{Introducing The Sexual Contract}

Without doubt, The Sexual Contract has a special place in feminist thought. Published thirty years ago, the work has inspired a broad range of ground-breaking scholarship and is a classic text in political theory and jurisprudence. It is historically important in making visible the patriarchal dimensions of the original contract-the sexual contract. "Looking back, I'm not actually quite sure when I thought of...the term, "the sexual contract'", says Pateman. Indeed, the genesis

Sharon Thompson

ThompsonS20@cardiff.ac.uk

1 Cardiff University, Cardiff, UK

2 University of California, Los Angeles, USA

3 School of European Studies, Cardiff University, Cardiff, UK 
of the book lay in her prior consideration of industrial democracy and worker cooperatives in Participation and Democratic Theory (1970) and in her exploration of the philosophy of Locke, Hobbes and Rousseau in The Problem of Political Obligation (1979). Work undertaken for these first two monographs affirmed for Pateman that the social contract was only part of a powerful and deeply-rooted cultural story about what binds society. It was by reading, writing about, and teaching feminist scholarship in the 1970s that Pateman later "realised there was this other dimension of contract" (see Brennan and Pateman 1979). For Pateman, feminism "offered a different way of looking at all of this" and hence The Sexual Contract emerged as being "partly about the classic texts... and partly my rereading of them once I'd got this feminist perspective which made it all look so different".

The Sexual Contract located patriarchy, and gave it a history, within the original contract. "One thing that runs right through the book", she says, "is the fact that contract, in my argument is central, as in practice it is the way in which an important form of subordination occurs." By identifying the sexual contract as being part of the original contract, conventional assumptions about contract are subverted completely. The orthodox interpretation of contract, as the basis of freedom, is dealt a critical blow as Pateman meticulously argues across each chapter that freedom is predicated on subordination. Thus her "big message", was that "men governed women" while political theory promulgated a myth that all citizens of the social contract are equal. It was this powerful myth, embedded in notions of contract, that obscured the fact of women's subordination. Pateman explains:

By the time I was writing the book...women were, more or less anyway, equal citizens. But in fact...you couldn't ever forget that you were women. We're not these individuals in exactly the same way that men are. For example, although...many more wives were working or in paid employment...they were not seen in exactly the same way as male workers.

Hence, The Sexual Contract is focused on social structures, exploring "marriage as an institution. Or, employment as an institution". This explanation may be helpful for those who mistakenly assume that the book is simply about legal contracts between individuals. It is Pateman's alternative way of thinking about contract that constructs a damning critique of existing social structures and institutions:

Of course, there are contracts between individual men and women. That's how you become husband and wife or employer and employee, or employer and worker or whatever terms you want to use. But that's not so much the point. In fact, I would say you can't understand what's going on when there's a contract between the two people if you don't also understand something about the institution, because you've got to know what 'marriage' means, it's part of one of the major structures of the society. In the book I wasn't talking about individuals in large part. I was talking about husbands and wives which is an entirely different thing...they're social categories or political categories. John Stuart Mill points out that you can have husbands who ill-treat their wives and you can have husbands who behave absolutely wonderfully. But the point is that 
the institution of marriage gives each husband the capacity, if he so wishes, to ill-treat his wife.

For Pateman, securing a link to praxis in her writing was key. Her ambition was for the book to show in practical terms how the sexual contract affects actual life and human behaviour. She achieved this by homing in on contractual formulations of marriage, employment, prostitution and surrogacy. This device made the book widely accessible because her ideas were practically tethered to assumptions about family, work, heterosexual sex and childbirth which were, and remain, central to cultural constructions of womanhood and impact on all women even though they do not in practice form part of every woman's life at an individual level.

One thing I had always been keen on right from the very beginning in my first book, was that I...got some empirical evidence in there as well as the theory. And I've always been rather keen...that you don't just have this abstract argument...I think this is why I didn't become a philosopher (laughs). That was why I started looking at these various contracts. The marriage contract is particularly important, as is the employment contract, I think it is in a way almost as important as the marriage contract. And then the newer ideas of the prostitution contract and the surrogacy contract.

It is no surprise that The Sexual Contract has had a major influence in socio-legal scholarship. Socio-legal feminists, likely schooled in the orthodox understandings of freedom of contract and jurisprudence, have experienced a law school education too often premised on old-fashioned (and inadequate) notions of the liberal individual. Encountering Pateman's argument that, through contract, employment, marriage, prostitution and surrogacy are in fact characterised by subordination, provides them with a transformative legal understanding of contract and gender.

Although her two earlier books have been hugely successful in their own right (remaining in print and on the syllabus of many politics modules in universities around the world) it is The Sexual Contract that has captured a truly interdisciplinary audience (On 2010). Yet, Pateman still seems quite surprised by this, "somehow, I appear to have had a more eager reception in law schools than political science departments", she says, "that has been interesting". Indeed, it wasn't until Pateman began to work on her manuscript for The Sexual Contract that she recognised an expansion in her disciplinary repertoire to include an exploration of legal concepts, "I quite enjoyed it, so there's more of it in the 'Settler Contract', the chapter I wrote later in Contract And Domination, (2007) with Charles Mills".

\section{Before The Sexual Contract}

The Sexual Contract has been described as a 'seminal work' (Vincent 2007) which has marked an 'historically important juncture in the development of contemporary feminist thought' (Yeatman 1990). It is not difficult to see why. The Sexual Contract was, and continues to be, a bold and radical work which 
re-writes the idea of original contract, re-formulates notions of the social contract and illustrates the transformative power of feminist thought in defiance of narrowly-argued categories of 'belonging' within feminism's internal silos. To date, there is little written about the lives of women in academia, and this is especially apparent in the fields of law and jurisprudence since women's legal history has not, until very recently, been considered important enough for academic study (Auchmuty 2015). In the context of discussing The Sexual Contract, it is more than a little ironic to note that male privilege filters our social awareness of the information which is, or is not, relevant to understanding personal contributions to public life. In the hope of protecting each generation of women from the isolation of being cut off from their own history, biography and context is essential to understand how women have negotiated their 'portfolios' between the public and private spheres (Auchmuty 2015).

Understanding more about Pateman's background and her unorthodox journey into academia provides a richer understanding of what Pateman describes as her "take-no-prisoners" approach to written argument and it illuminates why her perspective on the orthodox is so distinctively critical.

I've never really thought about audiences. I've just been interested in writing the stuff...it sounds a bit odd, perhaps...I think because I came at this from such a different background and such a different route than most people, I wasn't entirely socialised into the way of academia.

Pateman's background was far from privileged. Born into a working-class family in a village in Sussex during the second world war, she recalls, "My mother always liked to say, 'and the midwife had to stay all night!' because of German bombers flying overhead". Having passed the 11+exam, Pateman was accepted at Lewes County Grammar School for Girls, although she will "never know how my parents found the money for my uniform, but anyway somehow they did, and I used to go in on the bus every day".

Although academically talented, there was no encouragement of her to stay on to do A Levels, which she puts down to a combination of both her socialclass and gender since often middle-class boys went to private school and middleclass girls could use the opportunities of grammar school to move from further to higher education:

I left school when I was sixteen. I took the O-Level exams. I got...I think eight. And thinking back it occurred to me some years ago that none of these teachers at the school said, 'Oh! You should stay on.' No. So I just left...I think the middle-class girls all stayed on.

Pateman married when she was quite young and moved away from her parents to live in Witney, near Oxford. She worked as a clerical worker and in the civil service at the Land Registry and took evening classes in English Literature. Pateman's home was not far from Ruskin College, an education institute set up at the turn of the twentieth century as a 'College of the People' to provide university-standard education (Wilkes and Sheppard 2014). Its correspondence courses 
offered a path breaking route into higher education for adults from the UK and overseas who could not financially afford to give up paid work. Although women were not excluded, the majority of its correspondence students were men said to be "engaged in laborious occupations, men to whom even the cost of the midnight oil was a serious drawback" (Editorial 1915). Ruskin College also offered residential courses, which originally had been men-only affairs but were opened to include women from 1919. Funded by the Trade Unions, Ruskin College represented a unique and revolutionary development in working-class education. Yet despite its acceptance of women as students, the institution had been designed for the advancement of working-class men and the creation of this space for workers' learning did not overturn social perceptions that participation in university education was a male preserve. Pateman had heard of Ruskin College, "but I thought it was for men!". Purely by chance, Pateman attended a party in Oxford at which she met a woman who opened her eyes. "I started chatting to this woman, you know, 'What you are you doing?'...she was at Ruskin! I didn't know there were any women there and I was extremely surprised."

Pateman had enjoyed doing evening classes, her tutor agreed to write her a letter of reference and with that, she applied to Ruskin College. There was no grand plan, she was motivated by an interest in learning and was accepted for study. Paying for college however was another matter and she faced an interview by three "quite elderly County Council people" who would decide whether to provide her with financial support. "I remember I went for the interview and they kept asking me what I would do afterwards. I didn't really know how to answer, because I hadn't even thought about that. I was just excited about the idea of doing this!" Perhaps her apparent lack of ambition was the reason why she was merely offered enough money to pay her bus fares until the Principal of Ruskin intervened on her behalf and secured a bursary to cover her fees.

"So that was how I came to go to Ruskin", Pateman recalls there were barely any women there, mostly men, and the game there was who was most working-class. Well, I couldn't possibly win that because I was a woman, so I didn't count (laughs)...the archetypal Ruskin student was still a miner who went down the pit when he was fourteen. Although, I had a great time there.

Ruskin College awarded its own internal diplomas and students also sat the Oxford University Postgraduate Diploma in Political Science and Economics. Pateman describes it as "rather strange" that, in a College with "nobody with any educational qualifications to speak of", students could sit the postgraduate diploma.

Pateman was keen to continue her studies in politics and economics, she sat entry exams for universities, including Oxford, "partly because it was nearby, but partly because it was Oxford! I mean, you know (laughs) everybody's heard of it, even if they're completely untutored they've heard of Oxford. So there it was...this chance set in front of me to write these exams... and we were living just down the road!". Not expecting anything to come of her application, Pateman was surprised to be accepted to study Philosophy, Politics and Economics (PPE) at Lady Margaret Hall. On hearing the news, "my mother had really no idea of what I was doing, but she 
was terribly pleased and proud...but it was an incredible culture shock for me...I had no idea LMH was quite an upper-class place".

Pateman completed her undergraduate degree in two years (as the diploma substituted for the first year), "studying with all these diplomat's daughters". It was at Ruskin that Pateman says she "found" political theory and "just loved it!". She was inspired by the writing of John Plamenatz in Man and Society and it was the history of political thought, the awareness that learned people had discussed and debated these ideas for centuries, that captured Pateman's imagination. But for Pateman at that time, the very thought of undertaking a doctorate was "beyond my grasp". Embarking on a postgraduate Bachelor of Letters programme (B.Litt.) appeared a more attractive option for a student now weary of examinations. Her supervisor, Brian Barry, was a source of inspiration and encouragement. Recognising the high calibre of Pateman's studies in the 'classics' of political theory, Brian suggested she not only switch from the B.Litt. to a doctorate programme but also told her to send her manuscript to Cambridge University Press. Pateman explains:

so I started writing what became this book on the thinkers. And then I got a bit stuck. What did I do next? Brian suggested I have a look at the work of G. D. H. Cole and for me, somehow, I don't know, it just came together...I sent the manuscript to Cambridge and one day this letter came through the letterbox and it said, 'We're going to publish this as a book' (Laughs). So that's how that happened...I didn't understand then that with a degree from Oxford I could have done all sorts of things! I just kind of went with it. So that's how I became an author.

Her viva came after the publication of Participation and Democratic Theory (1970) and Pateman remembers hearing an 'incredible noise' and learning that it was Cowley factory workers with chains marching up the High Street outside protesting the Industrial Relations Act 1971 as she sat inside defending her thesis: "It was really quite amusing that during the viva they were clanking up the High Street and we were in there talking about industrial democracy".

While Pateman's expertise in political theory was developed at Oxford, it was her later immersion in feminist texts that led to her re-reading, and effective re-writing in The Sexual Contract of the classic texts on social contract. When she was at Ruskin, Pateman recalls that "the women's movement had hardly got started". It was the publication of feminist texts in the early seventies that brought her to feminism:

When all these feminist books came out-not the academic ones, the original ones-that was a eureka moment! I mean, heavens! People writing about this! And so I just devoured them... Because you know...look what they're writing about! I agreed with every word of it.

Interestingly, these books didn't immediately influence Pateman's work: "I was hugely excited about those books but at that point it didn't seem to have much connection to what I was doing. I mean it took me ages to work that out, actually". It was through Pateman's teaching at the University of Sydney of a bespoke undergraduate module on 'The Political Economy of Women' that she realised the connection 
between the feminist literature she had read and her own academic writing. Indeed, Sydney was where she published her first feminist piece in 1979 and "by that time, I had kind of started to see how it...interrelated with the work I had been doing". She speaks about the connection between the women's movement and her academic work with genuine enthusiasm:

There were lots of things going on in the streets...by the early seventies...I thought this was the best thing that had ever happened. I had been reading Hobbes and Locke and Rousseau and so on for a few years, but suddenly it was like reading different books! There's all this stuff which either was never set for students to read or was just kind of, you know, skimmed over. And this suddenly leapt out at me-look, look! They had all been talking about marriage and men and women...it's very hard to describe now, the impact all those early books had because there had been nothing and we had never been taught about women writing things earlier and the kinds of things they wrote. And even...John Stuart Mill! We didn't read The Subjection of Women (1869). That wasn't in the curriculum. You read On Liberty (1863). Or Considerations on Representative Government (1862).

For readers of The Sexual Contract, these "eureka moments" are patent in Pateman's writing over and over again. Her feminist transformation of classic political theory and philosophy lifted a veil on what had not been taught in law schools or in political theory classrooms before-that it was through the exclusionary medium of contract, that institutions and structures of society we often take for granted, in fact serve to reinforce gendered power imbalance and subordinate women.

\section{Response to The Sexual Contract}

The Sexual Contract has made a fundamental contribution to the development of feminist theory, received world-wide acclaim, and has inspired generations of scholars across multiple disciplines. "It's just been wonderful, the number of people who have come up and said...what an influence it had on them", Pateman says. Furthermore, the significance of the book is underpinned by its relevance to a diverse range of cultures around the world, which is something she is very pleased about:

The book was written very specifically about Anglo-American countries and the common law tradition...But I've discovered people all over the place in very different cultures have still found it very useful...that's been...most pleasing that it has got this much wider audience than I would have ever expected.

It has been enormously gratifying for Pateman to observe that the term 'the sexual contract' has taken on a life of its own beyond the book, "people refer to it as a 'thing', and I never know whether they've actually read the book or not (laughs), but it is terrific!". However, Pateman found that when the book first appeared in print, some of her reviewers deeply misunderstood it, possibly because they "focused on various chapters" in isolation when The Sexual Contract is "meant to be read from 
the first page to the last". This might be why "a lot of them really said nothing about the employment contract", for example, but instead "focused on the marriage contract". Some reviewers also misunderstood the idea of the sexual contract, in that they read it as coming before the social contract, "which actually is not what I said at all!". Pateman notes, "I said they're both part of the original contract. One doesn't really come before the other because the original contract is just a story anyway". In the late 1980s, when the The Sexual Contract was published, essentialism was a major issue in feminism circles. Previously, Pateman has shared her concern that "essentialism hunters" had overlooked the arguments she actually made in their fervour to identify perceived essentialism (On 2010). Yet the deep historical rooting of Pateman's work gives her a long-view perspective on the significance of feminism for political theory and, an awareness in particular that critiques of essentialism have a very long history (for example, in the work of Mary Wollstonecraft in the eighteenth century). While essentialism can be a problem, Pateman's work highlights sexual difference as a political difference between men and women, located in the thought of the classic contract theorists. She affirms:

I regarded feminism as offering a different way to look at all that. And I couldn't see the point of having divisions between labels of liberal feminism and socialist feminism, etc., etc., etc. You know, there was feminism! And that is what I used. Of course, it didn't stop people, after the book was published, from trying to stuff it into one of these categories. Usually, (puts on a posh voice) 'Oh she's a radical feminist.'

As a political scientist, it was the opportunity to bring feminism to "such, basic, important questions" about citizenship, democracy, participation and authority that gave Pateman a belief in feminism as a political and intellectual movement that would

really change the whole thing!...but that hasn't happened... while feminist ideas have changed some things, it hasn't been a big enough change. Certainly, there are many more women in political science...but everyone can be in their own little area of work without necessarily taking a great deal of notice about what other people are doing.

\section{The Sexual Contract Today}

It is interesting to consider Pateman's own response to reading The Sexual Contract once again in preparation for her opening address to the upcoming conference at Cardiff University and this interview. She quietly reflects, "on the whole I quite like it, actually (laughs)". Considerable legal and economic changes have produced and reflected changes in patriarchy but women's subordination to men is a recurrent theme, as Pateman muses: 
I haven't changed my mind about any of the major things in the book. And I still think The Sexual Contract has application now, although you have to take into account that society is not quite the same as it used to be.

The Sexual Contract continues to be widely regarded as one of the most important challenges to assumptions made in political theory and it has become a classic second-wave feminist text (Mills 2007, 79). The significance of its ongoing relevance should not be underestimated:

There have been big changes over the last thirty years and patriarchy is obviously not exactly the same as it was. Social mores have changed quite a bit. In particular there has been a lot of migration. People move around a lot and many of the old industries that I talk about in the book have gone. I mean mining has gone more or less completely. Printing is all computerised. So, the old working-class industries that supported the breadwinners that are in the book, they're not available any more. Jobs today seem to be awfully low-waged in this country.

Experience tells her that discussions of men's power over women fall in and out of intellectual fashion. For example, Pateman notes that the recent \#metoo campaign on social media in 2017 has powerfully brought the issue of sexual harassment back into public view and encouraged women to share their experiences of rape, sexual violation and unwanted sexual attention. This has drawn attention to the common place of harassment in women's lives and asserted women's right to speak for themselves and self-define the actions which harm them. However, an apparent focus on celebrity women has foreshadowed the day-to-day sexual harassment encountered by women unable to speak out for fear of losing their jobs and homes or jeopardising their intimate relationships. In this disparity of voice lies proof that the un-silencing of women in contemporary society is only partial. Pateman's enduring view of the underlying institutional contract and the domination/subordination dichotomy prompts her to question, "Despite \#metoo, how many men still think in exactly the same way? How many men have been influenced by the Harvey Weinstein scandal?"

The Sexual Contract is anything but dated, as is also clear in Pateman's analysis of demands for a basic income (Pateman 2004); a timely issue directly connected to her discussion of the employment contract thirty years ago. Pateman brings the gendered dimension of policy questions over basic income into sharp focus:

Basic income intersects with feminism because one thing that historically women have always lacked is an income. And particularly as wives...the 'breadwinner' was always the husband and if he was generous the wife could live reasonably well. But if not, not so. Therefore, a basic income would mean that really for the first time all women would have an income. But the crucial thing then is the level at which it is set. It becomes interesting when it's enough that you can live on... Not necessarily well, but you can live on it, so you can take part in things, and you don't have to worry where your next meal is coming from...I think, if you had it at that sort of level...it would at least 
allow people to not do some of the worst jobs and to get out of relationships where they're being beaten up. And then also, I thought if it was at a living level...people might start talking about other things. You know, how it is that women have not had an income like this before.

By abandoning a stance of gender-neutrality, Pateman's approach makes visible the liberating possibilities of basic income for women, such as escaping abusive relationships or being able to reject low-waged, poor quality jobs. The relevance of The Sexual Contract is also manifest in its contribution to other fields, such as critical race theory. Pateman is clearly passionate about this, particularly Charles Mills' work The Racial Contract (1997). "Oh I loved it!", she says, "it's very, very interesting stuff'. This culminated in Pateman and Mills' co-authored work Contract and Domination (2007). In this book, Pateman applied her vital perspectives on contract to theorise one of her other major contributions- 'The Settler Contract'. The settler contract exposes the deception of terra nullius or 'virgin territory' and undermines the arguments historically used to legitimise the states created in North America and Australia. The domination/subordination reinforced by the settler contract meant that the existence of the original inhabitants of these lands could only exist if expressly recognised by the new state (2007, 69). The formulation of this argument goes back to the late 1970s (2007, 35), as Pateman had "been collecting...material on terra nullius for a very long time". This research, building on the theoretical framework developed in The Sexual Contract, makes a ground-breaking contribution to critical race theory and socio-legal studies on indigenous land rights. And so it is not surprising that Pateman says "I regard The Settler Contract as my last significant piece". Through her oeuvre, Pateman has been able to explore the original contract through three interrelated dimensions: the social, sexual and racial contract.

When considering whether the institutional inequalities embedded in the sexual contract will be eroded in future, Pateman is not overly sanguine. In an interview with Nirmal Puwar (2002) Pateman anticipated an "interesting period over the next ten years if numbers of women in positions of political leadership go on increasing... we have plenty of examples of women who have been leaders of government that have not pushed an agenda that helps women". Fifteen years on, she now reflects on this statement about women in power:

There have not been very many female leaders who could be seen as having been influenced by the feminist movement. Very few of them, as far as I know, have actually done anything very specific for women...sometimes they have improved welfare policies... which obviously would have helped women.

In Pateman's view, "there...hasn't been a big enough cultural revolution yet" and while "a lot of feminist ideas... are now in popular circulation they exist in a very... watered-down form" and hence a lack of meaningful change has been achieved by women who do gain positions of power. Arguably the most persuasive explanation proffered by Pateman is that there are women pursuing policies that help women, but, she asks, "how likely is it that a woman of that sort would come to be in a position where she could be a leader of a country?" She goes on to say that there 
have "undoubtedly...been male politicians who have had policies that have helped women, but I don't think many of them have put it that way". When assessing why women do not gain power through helping women, perhaps our best explanation is provided by The Sexual Contract. This institutional contract, that she sets out so powerfully in her 1988 book, continues to underpin society today. And so, it is fitting that when asked what message she wants readers to get from the book now, Pateman responds:

I would hope that it might give them some insight...into the way that societies are structured. Even the best societies are still structured so that somehow men monopolise all the top positions, they get all the power.

\section{Conclusions}

Pateman's recollections about how The Sexual Contract came into being underline the fallacy of any attempt to regard equal opportunity and formal equality as a solution for the intellectual advancement of women's thought. How many more women with Pateman's scholarly capabilities and intellectual capacity did not discover new possibilities because they did not bump into a woman at a party who went to Ruskin College? While Oxford University was institutionally open, in a formal sense at least, it was the geographic proximity of its buildings and it physical presence in a town Pateman knew well that made it socially accessible to her.

Pateman returned to education as an adult in a setting shaped by and for workingclass men and later advanced her studies in a setting shaped by and for upper-class men. It is an inescapable conclusion that the boldness of her ideas in The Sexual Contract reflect her ability to understand gender from a working-class perspective and that this ability was sharpened by her educational circumstances and personal biography. The book offers a confident, assertive and clear account from a woman who remarks, "I wasn't at all confident (laughs)...it took me a very long time to develop any confidence about anything in life" but also recognises that by the time of writing The Sexual Contract she had learned "how to do it, how to put things together...I'm a woman who likes to make an argument, I'm not messing about, you know, I make an argument". Pateman's critical eye, her powerful written voice and her desire to challenge grand theories has been informed by her understanding of feminism as a call to keep focused on the big picture, speaking truth to power.

Women's education and scholarship are fundamentally significant as activities in the public sphere. Feminist writing and teaching is, in and of itself, a form of public sphere activism, producing and affecting social change by challenging fundamental tenets of assumed 'knowing' about the world. Pateman's account suggests The Sexual Contract is, in part, a product of her teaching about feminism and her own learning as an academic educator. It is a book inspired and informed by social experience located in the chasm between her sophisticated knowledge of political theory and the reality of what she knew of women's lives.

For academic feminists, questions of 'how to be' feminist and 'how to do' feminism necessarily recur in fresh contexts for each generation. Undoubtedly, feminism 
needs its writers and thinkers; those whose activism like Pateman's, is communicative, explanatory and endures as it is carried through the medium of education. Hence feminism needs its teachers too. When the orthodox understandings are so evidently wrong, it is patently inadequate for students to come to feminist explorations of contract as a supplementary addition to the orthodox. Young women, particularly working-class women, should not have to wait until post-graduate education or beyond to be introduced to scholarship which invites them to understand their historic exclusion and contemporary awareness of not quite fitting in.

Acknowledgements The Sexual Contract: 30 Years On, is a conference supported by Feminist Legal Studies and funded by the Cardiff Centre for Socio-legal Studies. It takes place between 10-11th May 2018. Details and updates can be found at https://sites.cardiff.ac.uk/events/view/the-sexual-contract-30years-on/.

Open Access This article is distributed under the terms of the Creative Commons Attribution 4.0 International License (http://creativecommons.org/licenses/by/4.0/), which permits unrestricted use, distribution, and reproduction in any medium, provided you give appropriate credit to the original author(s) and the source, provide a link to the Creative Commons license, and indicate if changes were made.

\section{References}

Auchmuty, Rosemary. 2015. Recovering Lost Lives: Researching Women in Legal History. Journal of Law and Society 42: 34-52.

Brennan, Teresa, and Carole Pateman. 1979. Mere Auxiliaries to the Commonwealth: Women and the Origins of Liberalism. Political Studies 27: 183-200.

Editorial. 1915. Ruskin Collegian, ed. H Alsop. Ruskin College.

Mills, Charles. 1997. The Racial Contract. Ithaca and London: Cornell University Press.

Mills, Charles. 2007. The Domination Contract. In Contract and Domination, ed. Carole Pateman and Charles Mills, 79-105. Cambridge: Polity Press.

Mill, John S. 1863. On Liberty. Boston: Ticknor and Fields.

Mill, John S. 1862. Considerations on Representative Government. New York: Harper and Bros.

Mill, John S. 1869. The Subjection of Women. London: Longmans, Green, Reader, and Dyer.

On, Steve. 2010. Interview with Carole Pateman. Contemporary Political Theory 9: 239-250.

Pateman, Carole. 1970. Participation and Democratic Theory. Cambridge: Cambridge University Press.

Pateman, Carole. 1979. The Problem of Political Obligation. Cambridge: Polity Press.

Pateman, Carole. 1988. The Sexual Contract. Cambridge: Polity Press.

Pateman, Carole. 2004. Democratizing Citizenship: Some Advantages of a Basic Income. Politics and Society 32: 89-105.

Pateman, Carole. 2007. The Settler Contract. In Contract and Domination, ed. Carole Pateman and Charles Mills, 35-78. Cambridge: Polity Press.

Pateman, Carole, and Mills, Charles. 2007. Contract and Domination. Cambridge: Polity Press.

Puwar, Nirmal, and Carole Pateman. 2002. "The Sexual Contract”, Women in Politics, Globalization and Citizenship. Feminist Review 70: 123-133.

Vincent, Andrew. 2007. The Nature of Political Theory. Oxford: Oxford University Press.

Wilkes, Chris, and Sheppard, Alan. 2014. The College and the Fellowship during World War I, Ruskin College Fellowship of Ex-Students. https://www.ruskin.ac.uk/perch/resources/the-ruskin-collegefellowship-and-the-first-world-war.pdf. Accessed 5 Feb 2018.

Yeatman, Anna. 1990. Review articles: Carole Pateman, The Sexual Contract (Polity 1988). Thesis Eleven 26: 151-159. 